\title{
PENDEKATAN SISTEM PEMBELAJARAN BAHASA ARAB DI MADRASAH MU'ALLIMIN MUHAMMADIYAH YOGYAKARTA
}

\section{APPROACH SYSTEM OF ARABIC LANGUAGE LEARNING AT ISLAMIC SCHOOL (MADRASAH) MU'ALLIMIN MUHAMMADIYAH, YOGYAKARTA}

\author{
Toni Pransiska ${ }^{1}$, Aly Aulia ${ }^{2}$ \\ ${ }^{1}$ STAI Sunan Pandanaran Yogyakarta \\ Jl. Kaliurang Km. 12,5. Ngaglik, Sleman 55581 \\ ${ }^{2}$ Universitas Muhammadiyah Yogyakarta \\ Jl. Brawijaya, Kasihan, Bantul, Yogyakarta 55183 \\ email: tonyelnoory@ymail.com \\ email: alydunk@gmail.com
}

Naskah Diterima: 28 April 2018; Direvisi: 15 Agustus 2018; Disetujui: 28 Agustus 2018

\begin{abstract}
This research examined the Arabic language development and learning at Madrasah Mu'allimin Muhammadiyah, Yogyakarta. Research diagnosed the components or sub-systems in Arabic language learning, which involved students, teachers, learning goals, methods, and Arabic text books. It is intended to describe the learning process of Arabic language in perspective of system approach. This research is a mixed research of qualitative and quantitative methods. In general, the interaction of sub-systems, namely students, teacher conditions, goals, methods, and text books is collaborative and cooperative. Even though, some problems were still found in each sub-system. The interaction of sub-systems in the learning process that implemented the interdependent, cooperative and dynamic principals, worked well. In addition, it is necessary to perform educational efforts to improve teacher competencies and student quality with education and training, workshop, seminar, text-book writing, comparative study, and direct practice. Therefore, the Arabic learning process may find an ideal format and solutive and educational steps in designing Arabic language learning that is active, conducive, creative, innovative, and fun.
\end{abstract}

Keywords: Development, Learning, Arabic Language, System Approach, Sub-system

\begin{abstract}
Abstrak
Penelitian ini membahas tentang pengembangan dan pembelajaran bahasa Arab di Madrasah Mu'allimin Muhammadiyah Yogyakarta. enelitian ini mencoba mendiagnosa komponen atau subsub system dalam pembelajaran bahasa Arab yang meliputi siswa, guru, tujuan pembelajaran, metode, dan buku ajar bahasa Arab.Hal ini dimaksudkan untuk mendeskripsikan proses pembelajaran bahasa Arab dalam perspektif pendekatan system. Penelitian ini merupakan jenis penelitian kombinasi (mix research) antara kualitatif dan kuantitatif. Secara umum, interaksi antar sub system seperti siswa, kondisi guru, tujuan, metode, dan buku ajar saling kolaboratif dan sinergis. Meskipun masih banyak ditemukan beberapa masalah di masing-masing sub system tersebut. Interaksi antar sub system tersebut dapat berjalan dengan baik dalam proses pembelajaran dengan melaksanakan prinsipi interdependensi, sinergitas, dan dinamis. Disamping itu, perlu melakukan upaya-upaya edukatif untuk meningkatkan kompetensi guru dan kualitas siswa dengan pendidikan dan pelatihan, workshop, seminar, penulisan buku ajar, studi banding (comparative study), dan praktek langsung (direct practice). Dengan begitu, proses pembelajaran bahasa arab dapat menemukan format ideal dan langkah-langkah solutif-edukatif dalam mendesain pembelajaran bahasa Arab yang aktif, kondusif, kreatif, inovatif dan menyenangkan.
\end{abstract}

Kata kunci: Pengembangan; Pembelajaran; Bahasa Arab; Pendekatan sistem; Sub sistem 


\section{PENDAHULUAN}

Di antara sekolah yang ada di Muhammadiyah, secara strukturalinstitusional, Madrasah Muallimin Muhammadiyah Yogyakarta memiliki posisi yang sangat strategis sebagai sekolah kader yang dinaungi langsung oleh PP Muhammadiyah dalam mencetak ulama, pemimpin dan pendidik. Posisi ini mengisyaratkan bahwa Muallimin membawa amanat besar dalam mendidik kader-kader Muhammadiyah menjadi ulama yang mumpuni di bidangnya dan menjadi pemimpin yang benar-benar membawa rakyat dalam 'pintu gerbang' kemakmuran, kemajuan dan berperadaban, serta menjadi pendidik yang turut andil dalam mencerdaskan kehidupan masyarakat sebagai salah satu cita-cita bangsa Indonesia.

Madrasah Muallimin sebagai institusi pendidikan formal, memberikan materi pelajaran umum dan keagamaan secara integratif dan proporsional. Terutamanya, penguasaan bahasa Asing -dalam hal ini bahasa Arab- menjadi penting untuk dikuasai oleh siswa Muallimin disamping bahasa Asing lainnya seperti bahasa Inggris. Namun, pengembangan dan pembelajaran bahasa Arab tidak berjalan 'mulus' di lapangan, jika dibandingkan dengan bahasa Inggris. Padahal, selama ini Madrasah Muallimin telah mengupayakan beberapa program dan kebijakan dalam mensukseskan dan mensupport pengembangan dan pembelajaran bahasa Arab.

Pertama, Secara penyelenggaraan pembelajaran, Madrasah Muallimin disamping memberikan pendidikan bahasa Arab di kelas, juga mewajibakan siswanya berasrama yang terintergrasi langsung dengan sekolah yang didampingi langsung oleh pembimbing asrama (musrif) dalam upaya mensupport kemahiran berbahasa Arab siswa. Sejatinya, hal ini mengisyaratkan akan adanya dukungan penuh (full support) dalam penguatan sistem pembelajaran bahasa Arab yakni dengan membentuk dan menciptakan lingkungan berbahasa Arab (biah lughawiyah). Disamping itu juga, adanya penambahan jam pelajaran (JPL) bahasa Arab. Madrasah Muallimin menambahkan jam pelajaran bahasa Arab yang terbilang banyak (8 JP/Pekan) ditambah dengan pengayaan di Asrama. Hal ini dilakukan agar memberikan efektifitas yang berarti dalam pembelajaran dan pengembangan bahasa Arab siswa.

Kedua, secara pembiayaan, Madarasah Muallimin merancang dan menyiapkan anggaran untuk program-program pengembangan bahasa Asing (Arab) di setiap tahunnya melalui staf urusan khusus pengembangan bahasa. Setidaknya, secara suport materil, Madrasah sangat mendukung, mengapresiasi dan mengupayakan agar siswa dapat menguasai bahasa Arab dengan baik.

Namun upaya yang telah dilakukan diatas tidak berbanding lurus dengan hasil yang diperoleh di lapangan dalam pengembangan dan penguasaan bahasa Asing (Arab). Berdasarkan data dan informasi di lapangan diperoleh fakta-fakta lapangan sebagai berikut;

Pertama, Kemahiran berkomunikasi (mahārah kalām) bahasa Arab masih rendah. Hal ini berdasarkan keterangan yang diperoleh dari salah seorang Guru bahasa Arab dan Pembimbing Asrama (musrif). Mereka menilai bahwa siswa masih lemah dalam percakapan sehari-hari (muhädasah), dan percakapan non formal lainnya. Disamping itu juga, motivasi belajar bahasa Arab siswa yang terbilang masih rendah. Hal ini tampak dari kurangnya keaktifan siswa di kelas dan antusiasme dalam mengikuti pembelajaran bahasa Arab. Sehingga, hal ini menjadikan lingkungan berbahasa tidak tercipta.

Kedua, Nilai Bahasa Arab (UAMBN) siswa masih rendah. Hal ini dapat dibuktikan dari rata-rata nilai rapot siswa pada mata pelajaran bahasa Arab dan ditambah dengan hasil Ujian Akhir Madrasah pada bidang bahasa Arab dalam lima tahun terakhir ini masih menunjukkan hasil yang rendah dan kurang maksimal.

Ketiga, Penerimaan studi lanjut di perguruan tinggi khususnya Timur tengah masih sangat minim. Bahkan berdasarkan informasi yang diperoleh bahwa tidak ada satupun siswa yang diterima di perguruan tinggi di Timur Tengah seperti Mesir, Sudan 
dan Maroko pada tahun 2016 ini. Sungguh hal ini menjadi tugas utama Muallimin dalam mengantarkan siswa-siswanya menuju bangku perkuliahan dan pengembangan karir lainnya.

Oleh karena itulah, tulisan bermaksud mengkaji lebih lanjut terkait problematika pembelajaran dan pengembangan bahasa Arab di Madrasah Muallimin secara komprehensif dan mendalam. Disamping mencoba menganalisa faktor-faktor krusial yang melingkupinya secara detail dan proporsional dengan mengkaji lebih mendalam terkait komponen-komponen pembelajaran khusus bahasa Arab yang ada. Komponen pembelajaran yang menjadi fokus penelitian yakni pada aspek Materi ajar, siswa dan Guru bahasa Arab. Sehingga hal ini diharapkan dapat memberikan kontribusi positif dalam pengembangan dan pembelajaran bahasa Arab di Madrasah Muallimin Muhammadiyah Yogyakarta dan sekolah-sekolah Muhammadiyah lainnya. Setidaknya, hal ini menjadi bahan evaluasi dan improvisasi sekaligus panduan dalam membuat kebijakan (decision making) dalam meningkatkan kualitas pembelajaran bahasa Arab di Madrasah Muallimin Yogyakarta. Penelitian ini diharapkan dapat memberikan kontribusi baik teoris-ilmiah maupun praksis. Adapun kontribusi teoritis penelitiian ini yakni menformulasikan dan mengembangkan teori pembelajaran pada bidang pendiidikan atau pembelejaran secara umum dan pembelajaran bahasa Arab khususnya. Adapun secara praksis, penelitian ini diharapkan dapat 1) memberikan gambaran umum mengenai problematika pembelajaran bahasa Arab di Madrasah Muallimin Yogyakarta sebagai bahan pertimbangan sekaligus acuan dalam merumuskan kebijakan yang sesuai dengan kebutuhan siswa (need Assessment). 2) menjadi landasan dan panduan sekolah-sekolah Muhammadiyah dalam mengembangan pembelejaran bahasa Arab. 3) memberikan rumusan strategi ideal dalam pengembangan Bahasa Arab.

\section{Telaah Literatur}

Pada bagian ini akan diuraikan mengenai kajian dan penelitian-penelitian terdahulu yang memiliki relevansi dengan penelitian yang akan dilakukan oleh peneliti. Relevansi tersebut bisa ditinjau dari aspek-aspek seperti tema kajian, cakupan (scope), fokus dan subyek penelitian, metode penelitian, perspektif yang digunakan, theoritical framework yang dijadikan sebagai pisau analisisnya dan lain sebagainya. Adapun beberapa penelitian dan kajian terdahulu tersebut diantaranya;

Pertama, Penelitian Ahmad Shobirin tentang "Upaya Inovatif Guru MTs dalam menyajikan materi bahasa Arab dan pengelolaan kelas pada pembelajaran bahasa Arab (Studi Kasus MTs YATPI dan MTs Miftahul Ulum)". Shobirin dalam hasil penelitiannya berkesimpulan bahwa upaya yang dilakukan dalam menyajikan materi bahasa Arab MTs YATPI dan MTs Miftahul Ulum dimaksudkan agar peserta didik dapat belajar secara aktif dan mampu secara mandiri dan esensi atas apa yang dipelajari bukan sebagai sebuah keterpaksaan dan beban. Penyajian materi yang kontekstual dimaksudkan agar memudahkan peserta didik memahami materi yang diajarkan. Pada pengelolaan kelas belajar yang meliputi keterampilan pemeliharaan iklim pembelajaran dan pengendalian kondisi kelas, guru telah melaksanakan pembelejaran secara humanis dengan melihat aspek psikologis dan sosial peserta didik. Hal ini menjadi alasan perlunya pengelolaan yang dilakukan agar peserta didik dapat belajar secara aktif dan kreatif. Penelitian ini memfokuskan kajiannya pada Kompetensi Guru dalam eksplorasi materi ajar bahasa Arab. Hal ini berbeda dengan penelitian yang akan dilakukan peneliti sendiri dimana fokus kajiannya adalah Guru bahasa Arab atau Musrif dan siswa serta materi ajar bahasa yang digunakan. ${ }^{1}$

Kedua, penelitian yang dilakukan oleh Dwi Lutfiyana tentang "Partisipasi Santri dalam Mengikuti Kegiatan Bi'ah Lughawiyah di Pondok Pesantren Ibnul Qoyyim Putra Yogykarta (Pendekatan Psikologis)'. Berdasarkan hasil risetnya, Dwi berkesimpulan bahwa; Pertama, menjadikan kegiatan

\footnotetext{
${ }^{1}$ Ahmad Sobirin. 2015. Upaya Inovatif Guru MTs dalam menyajikan materi bahasa Arab dan pengelolaan kelas pada pembelajaran bahasa Arab: Studi Kasus MTs YATPI dan MTs Miftahul Ulum, Thesis S2. Tidak diterbitkan, Pascasarjana UIN Sunan Kalijaga, h. 10
} 
bi'ahlugowiyyahsebagai program yang sesuai dalam pemerolehan bahasa kedua, melalui kegiatan penunjang bi'ah lugowiyyahseperti ilqa' mufradāt, muhadatsah, debat dan muhadharah akan menjadikan kegiatan berbahasa menjadi lebih bermakna karena keempat kegiatan tersebut saling terkait satu sama lain dalam pemerolehan bahasa kedua. Kedua, partisipasi aktif santri dalam mengikuti kegiatan bi'ah lughawiyah sangat terlihat ketika santri mulai menunjukkan wujud partisipasi timbal balik dalam mengikuti kegiatan, seperti bertanya ketika mendapati kesulitan ini sering terjadi dalam konteks kegiatan ilqa' mufradat dan muhadasah. Kemudian bentuk partisipasi timbal balik yang berupa respon aktif siswa terlihat ketika menyampaikan intisari dalam muhadharah dan mempertahankan argumen pada saat kegiatan debat (mujadalah) berlangsung. Ketiga, santri akan lebih termotivasi dan lebih berperan aktif dalam keikutsertaannya dalam kegiatan bi'ah lughawiyyah ketika guru atau musyrif selaku pembimbing mampu mengaplikasikan strategi yang inovatif. Santriakan terstimulus dengan strategi-strategi baru yang diterapkan dalam pembelajaran, terutama dalam pembelajaran bahasa asing. Penelitian yang dilakukan Dwi ini jelas sangat berbeda dengan penelitian yang akan peneliti lakukan dari segi perspektif dan pendekatan yang digunakan dalam menganalisa data-data di lapangan. ${ }^{2}$

Ketiga, penelitian Moch. Rosyid tentang "Muatan Ideologi dalam Kurikulum Bahasa Arab Terintegrasi (Studi Kasus di Madrasah Aliyah Ali Maksum Yogyakarta dan Madrasah Aliyah Islamic Center Bin Baz Yogyakarta)". Dalam hasil penelitiannya, Rosyid berkesimpulan bahwa pertama, muatan ideologi dapat dirasakan dalam kurikulum pembelajaran bahasa Arab yang terintegrasi dengan kurikulum pesantren (pembelajaran kitab kuning). Kedua, konsep ideologi yang digagas oleh kedua madrasah yakni MA Ali Maksum dan MA ICBB adalah konsep ideologi salaf. Namun salaf disini mempunyai konteks yang berbeda, MA Ali Maksum

${ }^{2}$ Dwi Lutfiyana, Partisipasi Santri dalam Mengikuti Kegiatan Bi'ah Lughawiyah di Pondok Pesantren Ibnul Qoyyim Putra Yogykarta: Pendekatan Psikologis. Thesis S2, 2015. Tidak diterbitkan. Pascasarjana UIN Sunan Kalijaga, h. 7-8 berdasar pada ideologi salaf ala Nahdlatul Ulama' sedangkan MA ICBB berdasar pada ideologi salaf ala kerajaan Arab Saudi atau yang dikenal dengan salafi. Ketiga, proses konstruksi yang terjadi dalam kurikulum bahasa Arab terintegrasi tersebut terdapat beberapa persamaan yakni kedua madrasah baik di MA Ali Maksum Maupun MA ICBB, adanya integrasi tersebut lebih mendukung kemampuan para peserta didik dalam maharah al-lughah pasif seperti qira'ah dan kitabah. Meskipun tidak menafikan adanya kemampuan bahasa Aktif yang ditargetkan kedua madrasah tersebut. Namun pada hakikatnya Maharah allughah pasif lebih mendominasi dalam integrasi tersebut. Adapun aspek pembeda penelitian ini adalah pada fokus kajian yang memusatkan pada materi ajar atau buku ajar yang digunakan di kedua sekolah tersebut dengan pendekatan sosiologis. Berbeda dengan penelitian yang akan dilakukan peneliti yang lebih memfokuskan pada aspek guru, siswa dan materi aja sekaligus dilihat dari perspektif teori kesisteman (system theory). ${ }^{3}$

Keempat, kajian oleh Ahmad Thalal Hasan dan Mahirom Ahmad tentang "Ta'lim al-Lughah al-Arabiyah al-Tawashuliyah li Thulab ghair al-Muslimin fi Jami'ah Malaysia Kelantan: al-Tajarub wa al-Tahaddiyah". Dalam penelitiannya, mereka mencoba mengidentifikasi problematika dalam belajar bahasa Arab Komunikatif bagi Siswa NonMuslim di Universitas Malaysia (UM) Kelantan. Adapun problem yang dihadapi oleh siswa non muslim ketika belajar bahasa Arab terdapat pada aspek-aspek berikut; Pertama, aspek Kitabah. Para siswa kesulitan menulis bahasa Arab baik bentuk terpisah (munfaridah) atau bersambung (mutashilah). Kedua, aspek pengucapan (al-nuthq). Adapun huruf-huruf yang dianggap sulit oleh siswa non Muslim dalam bahasa Arab adalah huruf $\dot{\varepsilon}-\varepsilon-\tau^{-}$ض. Sebab bagi mereka huruf-huruf tersebut tidak dimiliki dalam bahasa ibu mereka. Ketiga, aspek Percakapan (Muhādatsah). Sebagian

\footnotetext{
${ }^{3}$ Moch. Rosyid. 2014. Muatan Ideologi dalam Kurikulum Bahasa Arab Terintegrasi: Studi Kasus di Madrasah Aliyah Ali Maksum Yogyakarta dan Madrasah Aliyah Islamic Center Bin Baz Yogyakarta. Thesis S2. Tidak diterbitkan. Pascasarjana UIN Sunan Kalijaga. h. 8-10
} 
mereka belum terbiasa dan masih terbata-bata dalam mengungkapkan kalimat atau ungkapanungkapan sederhana. Muhādatsah ini mencakup tentang situasi-situasi umu seperti di restoran, Asrama, Stasiun Bus, Taman Kota dan lain sebagainya. Adapun upaya yang dilakukan sebagai langkah solutif dari problematika tersebut yakni; 1) Menganjarkan mereka bahasa melalui model Transliterasi. 2) membentuk kelas tambahan bagi mereka. 3) Membiasakan berbahasa Arab dalam lingkungan bahasa. Dengan pendek kata, bahwa pembeda penelitian terletak pada subyek dan objek penelitian. Siswa non muslim yang belajar bahasa Arab di Universita Malaysia Kelantan menjadi subyek penelitiannya. ${ }^{4}$

Kelima, penelitian oleh Nur Syuhada Muhammad dan Abd Wahab Zakaria (2011: 816-817) tentang "Ittijahat al-Thulabah nahw Ta'allum al-Lughah al-'Arabiyah fi alMadāris al-Diniyah al-Hukūmiyah alMāliziyah: al-Marhalah al-Tsanawiyah bi Wilayah Selangor Namūdzajan". Mereka berkesimpulan bahwa; 1) Mayoritas Siswa berorientasi positif terhadap belajar bahasa Arab. 2) adanya hubungan yang erat antara orientasi sisiwa dan keinginan mereka dalam belajar bahasa Arab. 3) guru memiliki peranan penting dalam menstimuli siswa dalam membentuk orientasi mereka terhadap belajar bahasa Arab. 4) belajar bahasa Arab memberikan bekal masa depan bagi siswa agar mereka mampu membaca al-Qur'an dengan mudah. 5) Meskipun banyak orangtua dari siswa yang tidak mengerti bahasa Arab, namun para orangtua senantiasi memotivasi anaknya untuk belajar bahasa Arab. Titik pembeda penelitian ini terletak pada Subjek dan Focus penelitian yakni orientasi belajar siswa Madrasah Keagamaan Negeri di Malaysia. ${ }^{5}$

${ }^{4}$ Ahmad Thalal Hasan dan Mahirom Ahmad. 2011. Ta'lim al-Lughah al-Arabiyah al-Tawashuliyah $l i$ Thulab ghair al-Muslimin fi Jami'ah Malaysia Kelantan: al-Tajarub wa al-Tahaddiyah. Prosiding Seminar Antarbangsa Pengajaran Bahasa Arab, Malaysia: Univeristas Kebangsaan Malaysia,, h. 13-18

${ }^{5}$ Nur Syuhada Muhammad dan Abd Wahab Zakaria. 2011. Ittijahat al-Thulabah nahw Ta'allum alLughah al-'Arabiyah fi al-Madāris al-Diniyah alHukūmiyah al-Māliziyah: al-Marhalah al-Tsanawiyah bi Wilayah Selangor Namūdzajan. Prosiding Seminar
Keenam, penelitian yang dilakukan oleh Kamiludin tentang "Problematika Pembelajaran Muhadtsah di Kelas VIII Madrasah Mu'allimin Muhammadiyah Yogyakarta tahun Pendidikan 2007/2008”. Hasil temuan penelitian ini menunjukkan bahwa problematika yang terjadi di Mu'allimin terdiri dari beberapa faktor diantaranya faktor siswa meliputi latar belakang pendidikan, motivasi, perasaan siswa ketika mengikuti pelajaran, kesulitan bermuhadtasah dan minimnya mufradāt serta antusiasme siswa di kelas. Faktor guru meliputi kompetensi guru bahasa Arab, kejelasan penyampaian materi, persiapan guru sebelum mengajar. Disamping faktor-faktor lainnya seperti materi, waktu, fasilitas, sosial atau lingkungan dan lain sebagainya. Penelitian memiliki fokus kajian pada pembelajaran muhādatsah secara spesifik. Dan hanya menngidentifikasi dan menganalisa problematika yang melingkupinya. Sementara penelitian yang akan peneliti lakukan mengenai pengembangan dalam arti model, pengayaan bahasa Arab di luar jam belajar mengajar. Dan juga pembelajaran yakni terkait metode, strategi, partisipasi siswa, dan materi ajar. ${ }^{6}$

\section{METODOLOGI PENELITIAN}

Penelitian menggunakan penelitian kombinasi atau camuran (mixed research) antara kualitatif dan kuantitatif. ${ }^{7}$ Hal ini dapat dilihat dari teknik pengumpulan datanya yakni kuesioner, indept interview, observasi dan dokumentasi. Metode penelitian kombinasi ini dilakukan agar diperoleh data yang lebih komprehensif, valid, reliable, dan obyektif. Penelitian ini dilakukan pada rentang waktu Januari-Juni 2017. Adapun setting Penelitian ini dilakukan di Madrasah Muallimin Yogyakarta dengan pertimbangan dan alasan diantaranya: 1) Madrasah Muallimin

Antarbangsa Pengajaran Bahasa Arab, Malaysia: Univeristas Kebangsaan Malaysia. h. 816-817.

${ }^{6}$ Kamiluddin, 2008. Problematika Pembelajaran Muhadtsah di Kelas VIII Madrasah Mu'allimin Muhammadiyah Yogyakarta tahun Pendidikan 2007/2008. Thesis S2. Tidak diterbitkan. Pascasarjana UIN Sunan Kalijaga, h. 75-88.

${ }^{7}$ Sugiyono, 2014, Metode Penelitian Manajemen, Bandung: Alvabeta. h. 470 
Muhammadiyah sebagai sekolah kaderisasi Muhammadiyah yang dinaungi langsung oleh PP Muhammadiyah. 2) Madrasah Muallimin Muhammadiyah dapat menjadi representasi dari beberapa sekolah atau Madrasah di lingkungan Muhammadiyah. 3) Asesibilitas data dan informasi penelitian baik lokasi dan keefektifan waktu. Subjek penelitian dalam penelitian ini ditentukan dengan teknik purposive sampling. Adapun yang menjadi fokus sekaligus subyek penelitian dalam hal ini adalah: 1) Siswa Madrasah Muallimin Yogyakarta kelas 4 dan 5 Keagamaan; 2) Guru bahasa Arab ; dan 3) Materi ajar bahasa Arab kelas 4 dan 5 .

Adapun teknik pengumpulan data dalam penelitian ini menggunakan pertama, teknik interview mendalam dengan beberapa narasumber seperti Direktur, guru bahasa arab dan siswa. Kedua, observasi berupa kegiatan belajar mengajar di kelas dan pengembangan bahasa Arab di asrama. Ketiga, dokumentasi. Teknik ini digunakan untuk mengumpulkan data-data dokumen, berkas, dan kepustakaan seperti buku ajar bahasa Arab yang digunakan di Madrasah Muallimin Yogyakarta.

\section{HASIL DAN PEMBAHASAN}

\section{Sekilas \\ Madrasah \\ Muhammadiyah Yogyakarta}

Muallimin

Madrasah Mu'allimin Muhammadiyah Yogyakarta (selanjutnya disebut Mu'allimin) didirikan oleh K.H. Ahmad Dahlan pada tahun 1918 dengan nama "Qismul Arqa" yang kemudian diubah menjadi Pondok Muhammadiyah (tahun 1920), lalu menjadi "Kweekschool Muhammadijah" (1924). Baru pada Kongres Muhammadiyah tahun 1930 di Yogyakarta berubah menjadi "Madrasah Mu'allimin Mu'allimaat Muhammadiyah". Setahun kemudian madrasah ini dipisah, Madrasah Mu'allimin Muhammadiyah (khusus putra) berlokasi di Ketanggungan Yogyakarta dan Madrasah Mu'allimaat Muhammadiyah (khusus puteri) berlokasi di Kampung Notoprajan Yogyakarta.

Pada Kongres Muhammadiyah Ke-23 tahun 1934 di Yogyakarta, ditegaskan bahwa Madrasah

Mu'allimin-Mu'allimaat Muhammadiyah Yogyakarta merupakan
Sekolah Kader Persyarikatan Muhammadiyah yang diselenggarakan oleh Pimpinan Pusat Muhammadiyah.

Pada Kongres Muhammadiyah di Medan tahun 1938 dua Madrasah ini memperoleh pengukuhan secara formal. Pada saat itu, Kongres mengamanatkan kepada Pimpinan Pusat Muhammadiyah sebagai pengelola dan penanggungjawab keberadaan dua madrasah ini di Yogyakarta. Pada tahun 1994, dua madrasah ini kembali memperoleh penegasan ulang melalui surat keputusan PP Muhammadiyah No. 63/SK-PP/VI-C/4.a/1994 tentang Qoidah Madrasah Mu'alliminMu'allimaat Muhammadiyah Yogyakarta.

Dalam proses perkembangannya, Mu'allimin senantiasa melakukan penyesuaian program pendidikannya dengan perkembangan zaman. Pada tahun 1980, dilakukan perubahan sistem pendidikan Mu'allimin yang sangat mendasar. Jikalau pada masa sebelumnya maskan atau asrama belum menjadi satu kesatuan sistem dengan madrasah, maka sejak tahun 1980, Mu'allimin mulai menganut sistem "long life education". Sistem ini, menegaskan bahwa madrasah/sekolah dan maskan/asrama adalah satu kesatuan yang tidak terpisahkan dalam proses pelaksanaan program pendidikan. Sistem ini pula yang menjadikan Mu'allimin mendapat pengakuan sebagai Pondok Pesantren dari Departemen Agama RI pada tahun1984.

Kemudian untuk memperkuat kurikulum pendidikannya, pada tahun 1987 dilakukanlah upaya resistematisasi kurikulum Mu'allimin. Upaya ini bertujuan agar proses pendidikan dan pengajaran dapat lebih berdaya guna dan berhasil guna. Dalam upaya ini ditetapkan kebijakan untuk menyusun suatu paket terpadu yang menyangkut materi bidang studi Al-Islam dan Kemuhammadiyahan dengan teknik kurikulum silang (crossing curriculum), yakni memadukan materi Madrasah Tsanawiyah dan Madrasah Aliyah Departemen Agama RI dengan materi Mu'allimin yang merujuk kepada referensi "kitab kuning". Selanjutnya dengan adanya UU Sisdiknas No. 20 Tahun 2003 dan Permenag No. 2 Tahun 2008 maka Mu'allimin mengacu pada 8 Standar Nasional Pendidikan (SNP) dan diperkaya dengan Permenang Tahun 2008 tentang Standar Kompetensi lulusan dan standar isi Pendidikan 
Agama Islam dan Bahasa Arab di Madrasah, sehingga menjadi begitu banyak jumlah muatan yang harus dipelajari siswa Mu'allimin terlebih dengan materi sekolah kader persyarikatan, maka tahun 2011/2012 Mu'allimin membuat terobosan untuk kurikulum formal dan informal dengan materi dalam kesatuan manajemen. Hal ini dimaksudkan untuk efektifitas dan efisien. Pada sisi lain agar tujuan masing-masing pemangku kepentingan dalam hal ini Pemerintah (Kemendikbud dan Kemenag) dan Persyarikatan bisa tercapai sehingga dengan "Long Life Education" siswa belajar secara formal dan informal dalam satu pengawasan.

\section{Pembelajaran Bahasa Arab di Madrasah Muallimin Yogyakarta: Sebuah Pendekatan Sistem}

Memandang aktivitas pembelajaran sebuah sistem dikenal dengan istilah pendekatan sistem (system approach). Melalui pendekatan sistem, kita dapat memahami proses pembelajaran sebagai suatu hal yang perlu dirancang secara sistematik dan sistemik. Kalau kita anggap pembelajaran sebagai suatu sistem, maka di dalamnya harus memiliki komponen-komponen yang berproses sesuai dengan fungsinya hingga tujuan pembelajaran tercapai secara optimal. Oleh karena itu, dalam hal ini pembelajaran bahasa Arab di Madrasah Muallimin Yogyakarta diasumsikan sebagai sebuah sistem yang memiliki unsur dan komponen yang saling bersinergi dan terintegrasi satu dengan yang lainnya. Adapun rincian penjelasannya sebagai berikut.

\section{Kondisi Siswa}

Siswa merupakan komponen penting dalam sistem pembelajaran di sekolah karena siswa merupakan subyek dari proses dan aktivitas pembelajaran itu sendiri. Pembelajaran harus menjadi sebuah aktivitas yang berfokus pada siswa (learner centered). Dalam konteks penelitian ini, peneliti mengambil sampel siswa kelas X Agama dan Kelas XI Agama Madrasah Muallimin Yogyakarta tahun pendidikan 2017/2018. Yang jumlahnya kelas X Agama sebanyak 33 siswa. Sedangkan jumlah siswa kelas XI Agama ada 26 siswa. Ada beberapa karakteristik umum siswa yang perlu mendapatkan perhatian dalam mendesain proses atau aktivitas pembelajaran yang efektif dan efisien.

Pertama, Latar Belakang Pendidikan dan Pengetahuan Awal (Entry Behavior). Berdasarkan data yang berhasil dihimpun bahwa seluruh siswa kelas $\mathrm{X}$ dan kelas XI Agama Madrasah Aliyah Muallimin (MA) Yogyakarta merupakan alumni dari Madrasah Tsanawiyah (MTs) Muallimin sendiri. ${ }^{8}$ Dengan kata lain bahwa latar belakang pendidikan mereka sebelumnya memberikan dan membekali mereka pengetahuan awal mengenai bahasa Arab. Sehingga dengan demikian, hal itu memudahkan mereka dalam belajar dan mengembangkan kemampuan bahasa Arab mereka. Dari berbagai penelitian diketahui bahwa siswa yang mempunyai pengetahuan dasar yang kuat dari proses belajar sebelumnya, mencapai prestasi yang lebih baik pada proses belajar berikutnya. ${ }^{9}$ Artinya, modal pengetahuan dasar bahasa Arab siswa saat mereka di jenjang MTs akan membantu mereka mempelajari tema atau materi selanjutnya ketika mereka berada di MA.

Kedua, Gaya Belajar atau Modalitas. Berdasarkan hasil observasi di lapangan menunjukkan bahwa gaya belajar atau modalitas siswa dalam belajar, memahami, menghafal, menerima dan menangkap informasi terkait bahasa Arab sangatlah beragam dan variatif sesuai dengan modalitas yang mereka miliki. ${ }^{10}$ Ketiga. Pada konteks penelitian ini, tingkat motivasi belajar bahasa Arab siswa secara umum dapat dilihat dari minat dan antusiasme mereka dalam mengikuti pembelajaran bahasa Arab.

\section{Kondisi Guru}

Proses pembelajaran tidak akan lepas dari tugas dan peran seorang guru atau pengajar. Dalam hal ini dapat dilihat pada dua

${ }^{8}$ Direktur Madrasah Muallimin, Wawancara, 10 Mei 2017, di Madrasah Muallimin Muhammadiyah Yogyakarta

${ }^{9}$ Iskandarwassid dan Dadang Sunendar, Strategi Pembelajaran Bahasa, (Bandung: Rosyda Karya, 2011), h. 136

${ }^{10}$ Berdasarkam hasil observasi kelas X Agama Madrasah Aliyah Muallimin Muhammadiyah Yogyakarta pada 5 Mei 2017 
kompetensi yakni; pertama, kompetensi pedagogik. Indikatornya adalah 1) gaya mengajar guru; Diketahui bahwa gaya mengajar guru di kelas cukup menarik $(13 / 39.5 \%)$ siswa dalam belajar bahasa Arab. 2) jam tambahan bahasa Arab. Terlihat bahwa guru terbilang tidak pernah $(22 / 66,5 \%)$ memberikan jam tambahan di luar jam belajar di kelas untuk memperdalam bahasa Arab. 3) pemberian tugas atau PR. Diperoleh keterangan bahwa guru tidak pernah $(22 / 66,5 \%)$ memberikan tugas atau latihan bahasa Arab. 4) pengelolaan kelas. Respon siswa dalam hal ini menunjukkan bahwa guru kurang mampu $(19 / 57,5 \%)$ membuat suasana kelas yang kondusif (tenang) untuk belajar. Kedua, Guru juga harus memiliki kompetensi professional. Adapun indikatornya; 1) penguasaan dan penjelasan materi. Respon siswa mengenai hal ini menunjukkan bahwa penguasaan dan penjelasan guru terhadap materi cukup baik $(20 / 60,5 \%)$. 2) respon dan feedback. Jawaban mereka adalah cukup baik sebanyak 21 siswa (64\%).

\section{Tujuan Pembelajaran Bahasa Arab}

Adapun tujuan pembelajaran bahasa Arab di MA Muallimin Muhammadiyah Yogyakarta secara keseluruhan mengikuti amanat yang tertuang dalam berkas kurikulum 2013. Namun Madrasah Muallimin memiliki tim kerja yang menyusun buku ajar tersendiri di internal Madrasah. Akan tetapi tujuan pembelajaran bahasa Arab dari internal Madrasah masih terlalu umum dan luas. Perlu disusun tujuan pembelajaran bahasa Arab yang berjenjang (gradasi), dan mencakup aspek krusial lainnya seperti tujuan kognitif, afektif dan psikomotorik.

\section{Metode Pembelajaran Bahasa Arab}

Berkaitan dengan metode pembelajaran bahasa Arab, guru bahasa Arab di kelas X Agama dan kelas XI Agama MA Muallimin juga menerapkan beberapa metode pembelajaran. Akan tetapi, penggunaan metode pembelajaran guru masih terbilang kurang variatif. Sehingga hal ini menuntut kreativitas dan inovasi seorang guru dalam mendesain dan mengkreasikan metode atau stategi belajar bahasa Arab yang aktif, kondusif, kreatif, kompetitif dalam suasana yang menyenangkan.

\section{Buku Ajar Bahasa Arab}

Guru menggunakan buku ajar yang jelas dalam mengajar bahasa Arab baik di kelas X maupun di kelas XI. Buku yang digunakan di kelas X adalah Kitāb al-Lughah al- 'Arabiyah yang terdiri dari dua jilid dan buku Muqarraq al-Lughah al-'Arabiyah yang terdiri dari dua jilid juga. Akan tetapi, Jika ditinjau dari perspektif penyusunan buku ajar yang ideal, bahwa buku ajar tersebut sesungguhnya masih banyak kekurangannya. Hal ini terlihat dari absennya beberapa aspek penilaian seperti tempat terbit, tahun terbit, penerbit, ISBN, harga buku, kaset recorder, instrumen test, buku bacaan tambahan, gambar dan ilustrasi serta kamus pendamping, tidak memuat kompetensi yang ingin dicapai dan tidak diberikan petunjuk penggunaan buku.

\section{Strategi dan Langkah Edukatif dalam Sistem Pembelajaran Bahasa Arab \\ Sistem Pembelajaran Bahasa Arab: Sebuah Diagnosa Permasalahan}

Sebuah sistem pembelajaran tentunya tidak selamanya berjalan dengan mulus dan mudah. Ibarat sebuah komputer, apabila salah satu komponen atau sub-sistemnya mengalami kerusakan, maka dapat dipastikan komputer tersebut sedang mengalami kendala dan kerusakan. Sehingga akhirnya tidak dapat dioperasikan seperti biasanya.

Demikian halnya dengan sebuah sistem pembelajaran khususnya bahasa Arab, jika antar sub sistem atau komponen sistem ada mengalami hambatan dan kendala, maka tujuan pembelajaran akan berjalan tidak efektif dan efisien bahkan mengalami kegagalan mencapai tujuan pembelajaran itu sendiri. Oleh karena itu antar sub-sistem harus bersinergi dan berproses hingga terciptanya interaksi yang berkelanjutan yang dapat mengantarkan pada tercapainya tujuan pembelajaran.

Semua komponen dalam sistem pembelajaran memiliki peran dan fungsi yang saling terkait satu sama lain untuk mencapai tujuan yang telah ditetapkan sebelumnya. Kinerja buruk dari sebuah sub-sistem akan mempengaruhi kinerja sub-sistem lain yang 
pada akhirnya akan mempengaruhi kinerja sistem secara keseluruhan.

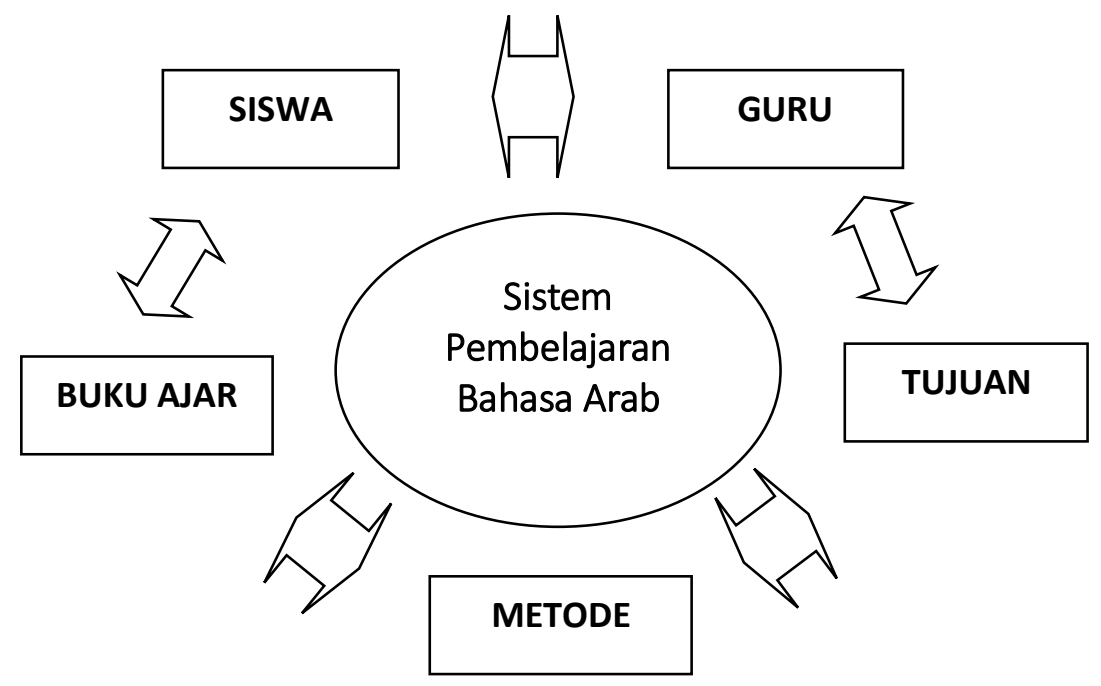

Gambar 1. Interaksi antarsub-sistem dalam sistem pembelajaran Bahasa Arab

Berdasarkan gambar diatas, komponenkomponen dari sebuah sistem yang disebut dengan sub sistem, akan melakukan aktivitas berupa proses, yaitu upaya untuk mentransformasikan input menjadi output. Output dari suatu sub-sistem digunakan sebagai input bagi sub-sistem lainnya. Oleh sebab itu, dalam konteks ini, peneliti mencoba mendiagnosa masing-masing sub-sistem apakah ada kendala yang berarti atau tidak. Dengan kata lain, mencoba memetakan dan menganalisa permasalahan yang terdapat pada sub-sub sistem pembelajaran bahasa Arab.

Tabel 1. Diagnosa kelemahan dan kelebihan antarsub sistem pembelajaran

\begin{tabular}{|c|c|c|}
\hline Sub Sistem & Kelemahan & Kelebihan \\
\hline SISWA & $\begin{array}{l}\text { - } \begin{array}{l}\text { Kurang mampu menemukan gaya } \\
\text { belajar atau modalitasnya sendiri }\end{array} \\
\text { - } \begin{array}{l}\text { Absennya konsistensi dan kontiniuitas } \\
\text { dalam penggunaan bahasa Arab }\end{array}\end{array}$ & 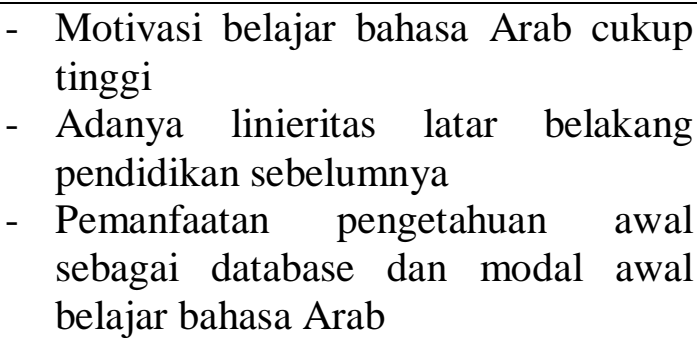 \\
\hline GURU & $\begin{array}{l}\text { - } \text { Tidak adanya jam tambahan dari guru } \\
\text { di luar kelas } \\
\text { - } \\
\text { Tidak adanya kegiatan evaluasi dengan } \\
\text { pemberian tugas, latihan atau PR } \\
\text { - } \\
\text { Kurang mampu mengelola kelas }\end{array}$ & $\begin{array}{l}\text { - Gaya mengajar guru dapat menarik } \\
\text { motivasi atau minat belajar bahasa } \\
\text { Arab siswa } \\
\text { - Guru dapat menguasai dan } \\
\text { menjelaskan materi dengan baik } \\
\text { - Guru cukup baik dalam memberikan } \\
\text { respon, tanggapan atau feedback } \\
\text { kepada siswa }\end{array}$ \\
\hline
\end{tabular}




\begin{tabular}{|c|c|c|}
\hline Sub Sistem & Kelemahan & Kelebihan \\
\hline TUJUAN & $\begin{array}{l}\text { - } \text { Tidak adanya gradualitas tujuan } \\
\text { pembelajaran baahsa Arab } \\
\text { - Perumusan tujuan pembelajaran bahasa } \\
\text { Arab tidak memperhatikan taksonomi } \\
\text { belajar yang mencakup kognitif, afektif } \\
\text { dan psikomotorik } \\
\text { - Tidak adanya rumusan tujuan } \\
\text { pembelajaran bahasa Arab berdasarkan } \\
\text { pada unsur-unsur kebahasaan (anāshir } \\
\text { lughawiyah) }\end{array}$ & $\begin{array}{llll}\text { Adanya } & \text { perumusan } & \text { tujuan } \\
\text { pembelajaran } & \text { bahasa Arab } & \text { secara } \\
\text { umum } & & & \end{array}$ \\
\hline METODE & $\begin{array}{l}\text { - Minimnya informasi mengenai varian } \\
\text { metode pembelajaran bahasa Arab } \\
\text { - Guru masih bertumpu pada satu metode } \\
\text { tertentu seperti metode qawa'id } \\
\text { tarjamah }\end{array}$ & $\begin{array}{l}\text { Adanya penerapan } \quad \text { metode } \\
\text { pembelajaran bahasa Arab yang } \\
\text { masih relevan dengan materi yang } \\
\text { diajarkan }\end{array}$ \\
\hline $\begin{array}{l}\text { BUKU } \\
\text { AJAR }\end{array}$ & $\begin{array}{l}\text { - } \begin{array}{l}\text { Buku ajar yang ada belum dapat } \\
\text { dikatakan sebagai buku ajar bahasa } \\
\text { Arab bagi non Arab yang ideal }\end{array} \\
\end{array}$ & $\begin{array}{l}\text { Tersedianya buku ajar bahasa Arab } \\
\text { kelas X dan kelas XI }\end{array}$ \\
\hline
\end{tabular}

\section{Langkah-langkah Solutif-Edukatif dalam Sistem Pembelajaran Bahasa Arab}

Diagnosa dan pemetaan permasalahan yang terdapat dalam 'tubuh' masing-masing sub sistem mutlak diperlukan dan dilakukan guna memformulasikan dan mengupayakan langkah-langkah pemecahannya. Langkahlangkah pemecahan masalah antar sub sistem tersebut dapat dilakukan dengan mempedomani dan melaksanakan prinsip dan karakteristik dari eksistensi sebuah sistem.

Pertama, Prinsip Interpendensi. Artinya bahwa setiap komponen yang terdapat dalam sebuah sistem memiliki ketergantungan antara sub sistem yang dengan yang lainnya untuk mencapai tujuan dan kinerja secara keseluruahan. Hasil atau output dari sebuah komponen yang terdapat dalam sebuah sistem akan menjadi input atau masukan bagi komponen-komponen sistem yang lainnya. Output dari siswa (motivasi belajar yang tinggi) dapat menjadi input bagi guru dalam menyampaikan materi pelajaran bahasa Arab. Gaya mengajar dan kompetensi guru yang mumpuni menjadi input untuk mencapai tujuan pembelajaran dan seterusnya.

Kedua, prinsip sinergitas. Artinya bahwa kinerja dari keseluruhan komponen yang terdapat dalam sebuah sistem akan berperan lebih optimal jika dibandingkan dengan kinerja setiap komponen yang bekerja secara masing-masing. Siswa tidak akan dapat belajar sendiri tanpa bantuan dan arahan seorang guru. Mengandalkan guru semata tanpa dibekali dengan penguasaan terkait metode pembelajaran juga akan menyita waktu lama. Metode secanggih apapun jika materi yang ingin diajarkan belum disusun dan diformulasikan dalam sebuah buku ajar, juga akan sia-sia. Dan seterusnya.

Ketiga, prinsip dinamika. Artinya sebuah sistem memiliki kemampuan untuk menyesuaikan diri dengan adanya perubahanperubahan yang terjadi di lingkungannya. Sebuah sistem menerima masukan atau input, melakukan proses dan menghasilkan produk atau output bagi lingkungannya. Sebuah sistem senantiasa berubah secara dinamis mengikuti perubahan yang terjadi di lingkungannya. Misalnya, antusiasme dan motivasi belajar bahasa Arab tinggi, hal ini menuntut guru harus dapat menyesuaikan dan menyeimbangkan dinamika yang terjadi pada siswanya. Guru memiliki kompetensi dan kecakapan dalam memgaplikasikan sebuah metode pembelajaran, namun juga harus memperhatikan karakteristik materi yang ingin diajarkan dan tujuan yang ingin dicapai dan begitu selanjutnya.

Disamping mempedomani dan melaksanakan prinsip-prinsip diatas, penting 
juga kiranya dilakukan upaya-upaya edukatif terutamanya pada aspek siswa dan peningkatan kompetensi guru. Partisipasi dalam Pendidikan dan Pelatihan (DIKLAT). Bentunkya bisa berupa 1) Inhouse training (IHT), yaitu pelatihan yang dilaksanakan secara internal di KKG/MGMP, sekolah/Madrasah atau tempat lain yang ditetapkan untuk menyelenggarakan pelatihan. Pelatihan ini tidak hanya dilakukan secara eksternal, tetapi dapat dilakukan oleh guru yang memiliki kompetensi lebih tingga dengan memberikan pelatiahan kepada sesama guru bahasa Arab (tutor sebaya). 2) pelatihan berjenjang dan kursus. Pelatihan ini dilaksanakan di Balai Pendidikan dan Pelatihan atau Pusat Pendidikan dan Pelatihan (PUSDIKLAT) kementerian Agama, P4TK atau LPMP dan lembaga lain yang diberi wewenang. 3) pembinaan internal Madrasah. Pembinaan ini dilaksanakan oleh kepala sekolah/Madrasah dan guru-guru yang memiliki kewenangan membina, melalui rapat dinas, rotasi tugas mengajar, diskusi dengan rekan sejawat atau pihak sekolah mendatang trainer pendidikan ke sekolah. 4) Pendidikan Lanjut. Pembinaan profesi guru melalui pendidikan lanjut juga merupakan alternatif bagi pembinaan profesi guru bahasa Arab di masa mendatang.

Kegiatan non Pendidikan dan Pelatihan. Bentuknya bisa berupa 1) diskusi masalah pendidikan yang diadakan pihak sekolah secara berkala dengan topik-topik faktual dan krusial. 2) mengikuti Seminar. Pertisipasi guru dalam kegiatan seminar baik level nasional maupun internasional dan pembinaan publikasi ilmiah juga dapat menjadi model pembinaan berkelanjutan profesi guru bahasa Arab dalam meninggkatkan kompetensinya. 3) workshop. Kegiatan ini dilakukan untuk menghasilkan produk yang bermanfaat bagi pembelajaran, peningkatan kompetensi maupun pengembangan karirnya. 4) Penulisan Buku Ajar. Yakni pembinaan mengenai menyusun atau menulis buku ajar yang baik dimentori oleh penulis-penulis profesional dan berpengalaman di bidangnya.

Bagi siswa kegiatan yang dapat menstimuli dan memantik semangat belajar bahasa Arab dapat berupa 1) study komparatif (studi banding) dengan sekolah atau Madrasahmadrasah yang menjadi model dalam pengembangan dan penerapan lingkungan berbahasa Arab yang baik. 2) direct practice (praktek langsung) yakni dengan mendatang native speaker bahasa Arab di salah satu negera Timur Tengah ke Madrasah sehingga dengan begitu mendapatkan pengalaman tersendiri.

\section{Kontribusi Penelitian bagi ilmu-Ilmu Keislaman}

Penelitian ini dilakukan berdasarkan analisa mendalam dan prosedur penelitian yang dapat dipertanggungjawabkan secara ilmiah, sehingga dengan begitu, penelitian ini diharapkan dapat memberikan kontribusi bagi pengembangan keilmuan (contribution of knowledge) terutama ilmu-ilmu keislaman (al'Ulūm al-Islāmiyah) yakni secara eksplisit mengenai Pendidikan bahasa Arab di Indonesia (Ta'lìm al-Lughah al-'Arabiyah $f i$ Indunisia). Oleh karena itu, dalam hal ini akan dipetakan kontribusi keilmuan penelitian ini ke dalam dua aspek.

Pertama, Edukatif. Hasil penelitian ini dapat dijadikan bahan pertimbangan pada aspek edukatif-pedagogis bahasa Arab. Aspek edukatif ini meliputi (a) tanaga pendidik (filosofi, kompetensi, dan wawasannya di bidang bahasa Arab, profesionalisme, dedikasi, etos kerja, dan etos keilmuannya dalam mengembangkan pembelajaran bahasa Arab); (b) peserta didik (minat, motivasi, kesan dan persepsinya tantang bahasa Arab, keluarga, dan kecerdasannya dalam belajar bahasa Arab); (c) metode pembelajaran (kebaruan, kemutakhiran, efektivitas, variasi dan pengembangannya, revitalisasi); (d) tujuan pembelajaran bahasa Arab (pemetaan, formulasi, gradualitas, futuristik, periodik); (e) buku ajar bahasa Arab (prinsip dan asas penyusunan, idealitas, seleksi, gradasi, repetisi, komplementer).

Kedua, Kelembagaan. Hasil ini penelitian ini dapat dijadikan pijakan dan arah acuan dalam pengembangan pembelajaran bahasa Arab di lembaga pendidikan islam integrasi. Artinya, sistem lembaga pendidikan yang terintegrasi langsung dengan asrama (boarding school). Hal ini tentunya menjadi nilai tambah (added point) dalam menciptakan lingkungan berbahasa Arab (takwin al-bi'ah al-lughawiyah) yang kondusif. Sebab 
penelitian sebelumnya yang pernah dilakukan oleh Krashen membuktikan bahwa lingkungan formal dan informal memengaruhi kemampuan berbahasa asing siswa dalam cara yang berbeda. ${ }^{11}$ Oleh karena itu lingkungan Madrasah Mua'llimin Muhammadiyah sebagai lingkungan formal dapat disinergikan dengan baik dengan lingkungan informal yaitu asrama. Lingkungan informal memberikan masukan bagi pemerolehan bahasa (iktisāb al-lughah), sedangkan lingkungan formal memberikan masukan bagi monitor (menyunting dan memperbaiki wacana kebahasaan yang telah dimiliki siswa melalui pemerolehan bahasa).

\section{PENUTUP}

Sistem pembelajaran bahasa Arab di Madrasah Mualliminj Muhammadiyah Yogyakarta secara keseluruhan dapart dikatakan masih banyak kekurangan dan kelemahan. Kendala itu terpada pada aspek guru yang mengajar bahasa Arab, tujuan pembelajaran yang perlu dipertegas, penerapan metode pembelajaran bahasa Arab yang perlu variatif dan beragam, perlu adanya buku ajar bahasa Arab yang benar-benar mewakili kebutuhan siswa dan masyarakat dan juga layak untuk menjadi buku ajar bahasa Arab bagi non Arab yang bermutu dan ideal.

Prinsip interdependensi, sinergitas dan dinamis harus benar dipegangi dan dilaksanakan agar sistem pembelajaran berjalan dengan efektif dan efisien. Prinsip interdependensi mengisyarakatkan bahwa setiap komponen yang terdapat dalam sebuah sistem memiliki ketergantungan antara sub sistem yang satu dengan yang lainnya untuk mencapai tujuan dan kinerja secara keseluruahan. Hasil atau output dari sebuah komponen yang terdapat dalam sebuah sistem akan menjadi input atau masukan bagi komponen-komponen sistem yang lainnya. Output dari siswa (motivasi belajar yang tinggi) dapat menjadi input bagi guru dalam menyampaikan materi pelajaran bahasa Arab. Gaya mengajar dan kompetensi guru yang mumpuni menjadi input untuk mencapai tujuan pembelajaran dan seterusnya. Prinsip

11 Muhbib Abdul Wahab, 2009. Pemikiran Linguistik Tammam Hassan dalam Pembelajaran bahasa Arab, Jakarta: UIN Jakarta Press, h. 266 sinergitas mengisyaratkan bahwa antar sub sistem harus berjalan bersama dan saling support satu sama lainnya. Siswa tidak akan dapat belajar sendiri tanpa bantuan dan arahan seorang guru. Mengandalkan guru semata tanpa dibekali dengan penguasaan terkait metode pembelajaran juga akan menyita waktu lama. Metode secanggih apapun jika materi yang ingin diajarkan belum disusun dan diformulasikan dalam sebuah buku ajar, juga akan sia-sia. Prinsip dinamis mengisyaratkan bahwa sebuah sistem memiliki kemampuan untuk menyesuaikan diri dengan adanya perubahan-perubahan yang terjadi di lingkungannya. Oleh karena itu, pembelajaran bahasa Arab sebagai sebuah sistem dapat berjalan dengan penuh progres, efektif dan produktif jika benar-benar mengamalkan ketiga prinsip sistem diatas. Di sinilah titik utama pendekatan sistem digunakan dalam menganalisa sebuah proses pembelajaran.

\section{UCAPAN TERIMA KASIH}

Terakhir penulis sampaikan terima kasih yang sebesar-besarnya kepada Majelis Pendidikan Tinggi Penelitian dan Pengembangan (Diktilitbang) PP Muhammadiyah atas dukungan baik moril maupun materil yang telah diberikan. Penelitian ini merupakan hasil penelitian yang didanai oleh Dana Hibah Penelitian Muhammadiyah Abad Kedua 2017. Semoga hasil penelitian ini dapat memberikan masukan penting (entry point) bagi pemangku kebijakan di Pendidikan Dasar dan Menengah Muhammadiyah dan bagi lembaga pendidikan lainnya dalam visi memajukan dan mencerdaskan kehidupan bangsa.

\section{DAFTAR PUSTAKA}

Abd Alim Ibrahim, (2007): al-Muwajih alFanny li Mudarrisī al-Lughah al'Arabiyah, Cairo: Dār al-Ma'ārif.

Abdul Majid, (2007): Perencanaan Pembelajaran, Bandung: Rosdakarya.

Ahmad Sobirin, Upaya Inovatif Guru MTs dalam menyajikan materi bahasa Arab dan pengelolaan kelas pada pembelajaran bahasa Arab: Studi Kasus MTs YATPI dan MTs Miftahul Ulum, 
Thesis S2. Tidak diterbitkan. 2015: Pascasarjana UIN Sunan Kalijaga.

Ahmad Thalal Hasan dan Mahirom Ahmad, (2011): Ta'lim al-Lughah al-Arabiyah al-Tawashuliyah li Thulab ghair alMuslimin fi Jami'ah Malaysia Kelantan: al-Tajarub wa al-Tahaddiyah. Prosiding Seminar Antarbangsa Pengajaran Bahasa Arab, Malaysia: Univeristas Kebangsaan Malaysia.

Azhar Arsyad. (2004): Bahasa Arab dan Metode Pengajarannya, Cet. 2, Yogyakarta: Pustaka Pelajar.

Bobbi De Porter dan Mike Hernacki, (2014): Quantum Learning, Cet. XVII, Bandung: Kaifa.

Burt, Dulay dan Krashen, (1982): Language Two, New York: Oxford University Press,

Dwi Lutfiyana, Partisipasi Santri dalam Mengikuti Kegiatan Bi'ah Lughawiyah di Pondok Pesantren Ibnul Qoyyim Putra Yogykarta: Pendekatan Psikologis. Thesis S2, 2015. Tidak diterbitkan. Pascasarjana UIN Sunan Kalijaga.

Iskandarwassid dan Dadang Sunendar, (2011): Strategi Pembelajaran Bahasa, Bandung: Rosyda Karya.

Joseph Devlin, (1961): A Dictionary of Synonims and Antonyms, Bandung: Penerbit Angkasa.

Kamiluddin, (2008): Problematika Pembelajaran Muhadtsah di Kelas VIII Madrasah Mu'allimin Muhammadiyah Yogyakarta tahun Pendidikan 2007/2008. Thesis S2. Tidak diterbitkan. Pascasarjana UIN Sunan Kalijaga.

Mastuhu, (2003): Menata Ulang Pemikiran Sistem Pendidikan Nasional Abad 21, Yogyakarta: Safiria Insania Press.

Moch. Rosyid, (2014): Muatan Ideologi dalam Kurikulum Bahasa Arab Terintegrasi: Studi Kasus di Madrasah Aliyah Ali Maksum Yogyakarta dan Madrasah Aliyah Islamic Center Bin Baz Yogyakarta. Thesis S2. Tidak diterbitkan. Pascasarjana UIN Sunan Kalijaga.

Nur Syuhada Muhammad dan Abd Wahab Zakaria. (2011): Ittijahat al-Thulabah nahw Ta'allum al-Lughah al-'Arabiyah fi al-Madāris al-Diniyah al-Hukūmiyah al-Māliziyah: al-Marhalah alTsanawiyah bi Wilayah Selangor Namūdzajan. Prosiding Seminar Antarbangsa Pengajaran Bahasa Arab, Malaysia: Univeristas Kebangsaan Malaysia.

Oemar Hamalik, (2008): Perencanaan Pengajaran Berdasarkan Pendekatan Sistem, Jakarta: Bumi Aksara.

Rostiyah, (1994): Masalah Pengajaran Sebagai Suatu Sistem, Jakarta: Rineka cipta,

Rusman, (2011): Model-model Pembelajaran Mengembangkan Profesionalisme Guru, Jakarta: Rajawali Pers.

Rusydi Ahmad Thu'aimah, (2004): al-Mahārāt al-Lughawiyah: Mustawayātuhā, Tadrīsuhā, Shu'ūbatuhā, Cairo: Dār alFikr al-'Araby.

Rusydi Ahmad Thu'aimah, (2004): al-Usus al'āmmah li Manāhij Ta'lìm al-Lughah al'Arabiyah, Cairo: Dār al-Fikr al-'Arabi.

Sugiyono, (2014): Metode Penelitian Manajemen, cet. ke-2. Bandung: Alvabeta.

Sukadi, (2008): Progressive Learning; Learning by Spirit, Bandung: MQS Publishing.

Syamsuddin Asyrofi dan Toni Pransiska, (2016): Penulisan Buku Teks Bahasa Arab; Konsep, Prinsip, Problematika, dan Proyeksi, Yogyakarta: Penerbit Ombak,

Syamsuddin, (2009): Metode Penelitian Pendidikan Bahasa. Bandung: PT. Remaja Rosdakarya.

Tim Penyusun Kamus Pusat Bahasa, (2005): Kamus Besar Bahasa Indonesia, Jakarta: balai Pustaka.

Tim Penyusun, (2007): Undang-undang Sistem Pendidikan Nasional, cet-3, Yogyakarta: Pustaka Pelajar.

Wina Sanjaya, (2008): Perencanaan dan Desain Sistem Pembelajaran, Jakarta: Prenada Media Group.

Yahya Hamid Hamdan dan Jabir Abd alHamid, (1978): al-Manāhij: Asāsuhā, Takhthītuhā, Taqwīmuhā, Cairo: Dār alNahdhah al-'Arabiyah. 
